\title{
LEDAKAN KREATIVITAS DAN KONTROL HUKUM DI ERA INTERNET
}

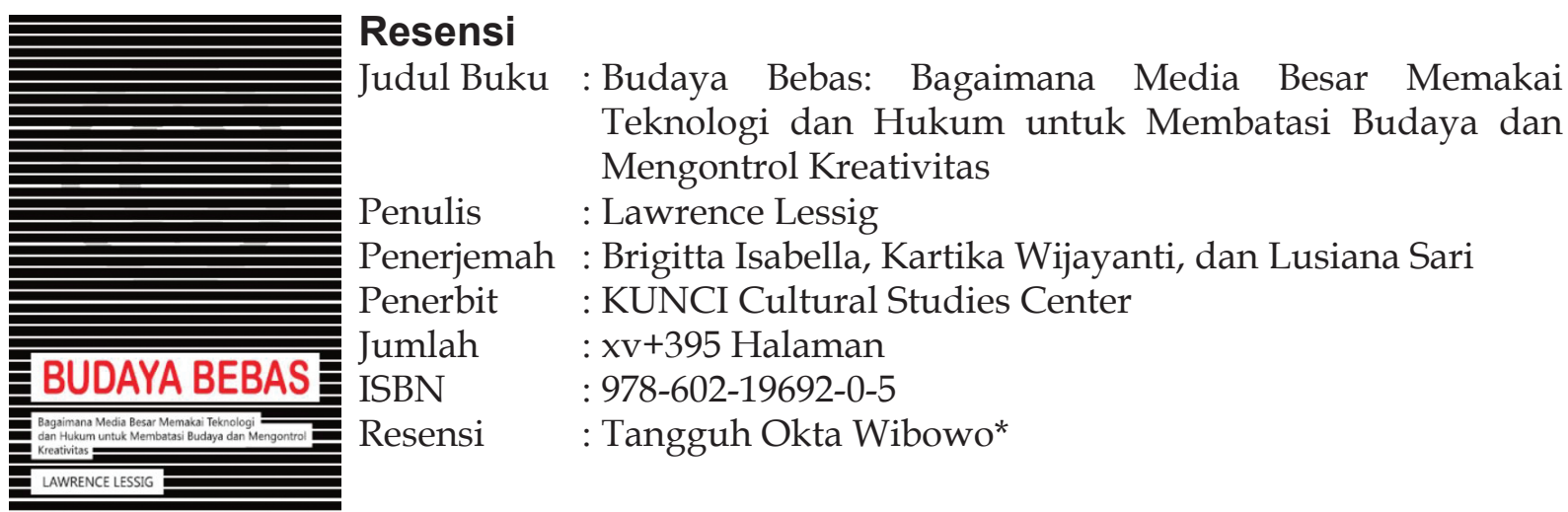

Sebuah buku yang ditulis oleh Lawrence Lessig di tahun 2004, seorang pengacara yang memberikan perhatiannya kepada isu yang tidak akan pernah selesai hingga memasuki abad 21 ini, yaitu perihal budaya bebas yang "mencuri" konten berhak cipta tanpa izin. Budaya bebas (Free culture) yang dijelaskan Lessig berbeda dengan free beers, tetapi bebas dalam arti kebebasan berpendapat, pasar bebas, perdagangan bebas, pemilihan suara bebas, dan berkehendak bebas. Inilah yang Lessig coba kritisi, yaitu budaya bebas yang hadir seiring dengan teknologi internet yang telah menyuburkan perubahan penting dan sekaligus tidak dikenali dalam proses produksi konten.

Di dalam bukunya ia mencoba melakukan pendekatan isu ini dengan menghadirkan beberapa cerita deskriptif untuk memberikan gambaran yang dekat dengan aktivitas ini. Ia menggambarkan bagaimana korporasi/ industri konten yang terancam oleh potensi Internet dalam mengubah cara diciptakannya dan disebarkannya budaya komersial mau-

Mahasiswa doktoral program studi Kajian Budaya dan Media, Sekolah Pascasarjana, Universitas Gadjah mada. pun nonkomersial. Mereka telah bersatu untuk "membujuk" pembuat hukum agar menggunakan hukum untuk melindungi konten mereka. Melalui buku ini dapat membuka sebuah sebuah pandangan bahwa pertarungan yang berkecamuk belakangan ini berpusat pada dua gagasan: "kepemilikan" dan "budaya izin". Tujuan utama dalam melobi regulasi bukan hanya perlindungan terhadap "properti" atau karya, tetapi memastikan hal tersebut menjadi milik mereka dan meminimalisir kompetisi ranah publik yang telah memiliki perangkat untuk menciptakan kreasinya sendiri.

Di sisi lain, berbicara tentang pembajakan, hukum telah mengatur tentang kepemilikan kreatif atau disebut hak cipta dan persebarannya sebagai hak intelektual. Peran hukum menjamin inovator baru untuk memiliki kebebasan dalam mengembangkan cara baru dalam menyampaikan konten dan menjamin bahwa kreator mendapatkan kompensasi dari karyanya. Internetlah yang memprovokasi perang ini. Internet memungkinkan persebaran konten yang efisien. Proses berbagi file ke sesama pengguna (peer-to-peer / $\mathrm{p} 2 \mathrm{p}$ ) merupakan cara berbagi file yang paling efisien dari 
teknologi-teknologi efisien yang disediakan Internet. Perubahan tersebut berarti bahwa seseorang dapat "mengambil manfaat secara gratis" dari karya orang lain.

Hal penting didapati dari pemikiran Lessig adalah bagaimana melihat budaya bebas ini di internet, yaitu mengambil "manfaat dari produk berhak cipta" orang lain tanpa membayar telah menjadi hal yang adiktif saat ini. Hal ini dikarenakan merupakan sebuah cara termudah untuk meraih akses ke beragam jenis konten.

Akan tetapi, jika menghitung kerugian akibat teknologi internet ini, tidak diragukan lagi bahwa sulit untuk menentukan ukuran yang pas untuk menghitung "kerugian" yang dialami suatu industri. Kompetisi tersebut mendorong para pesaing untuk menawarkan produk baru dan lebih baik. Ini merupakan hakikat dari yang disebut sebagai pasar kompetitif.

Terakhir, internet berada dalam transisi dan seharusnya tidak berusaha untuk mengatur teknologi dalam transisi tersebut. Di lima tahun kedepan, kreativitas untuk menciptakan sebuah karya dan distribusinya juga akan berubah seiring kemajuan teknologi internet tersebut. Sebaiknya membuat regulasi untuk meminimalkan kerugian atas kepentingan yang dipengaruh oleh perubahan teknologi ini, bukannya mencoba mengontrol internet dengan restriksi-restriksi. Terpenting adalah memastikan kompensasi bagi kreator tanpa menghancurkan Internet. Fokus dalam proses menuju ke sana seharusnya pada bagaimana memastikan agar para seniman dibayar, sambil melindungi ruang bagi inovasi dan kreativitas yang menjadi esensi dari Internet.

Buku ini sangat penting untuk dibaca oleh generasi pemuda untuk membuka pemikirannya agar tidak terjebak kepada logikan biner sederhana, benar atau salah dalam memahami ledakan kreativitas di tengah kemajuan teknologi internet yang masih bersifat sementara. Untuk melengkapi pemahaman budaya bebas ini, pembaca dapat membaca buku dari Lessig, yaitu Remix: Making Art and Commerce Thrive in the Hybrid Economy terkait Creative Commons sebagai alat yang legal untuk memberikan lisensi hak cipta untuk menandai kreativitas ranah publik. 